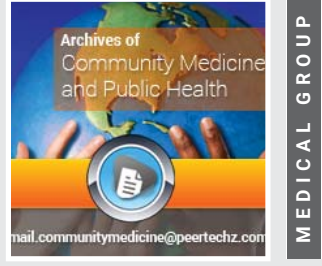

\title{
Passive immunotherapy using
} approved vaccines combined with lockdown, as essential parts of the community medicine and public health to survive and even beat

\section{COVID: A viewpoint commentary}

\author{
Jerard Seghatchian* \\ International Consultancy in Innovative Manufacturing and Quality/Safety of Blood-Derived Bioproducts. \\ London, England, UK
}

Mass vaccination campaigns are still underway to help in combatting the COVID-19 pandemic but timely production and distribution of approved vaccines is becoming a major unresolved problem worldwide. Meanwhile some new generation of vaccines, developed based on the characteristic profiles of the viral spike proteins and when deployed in the planned mass vaccination studies in the UK were found to be highly effective, to slow down the rate of hospitalization and to save life, Where the use of artificial intelligence and newer technological tools in big data and patterns analysis, were instrumental that we could not do without. Recently, however some very rare thrombotic adverse effects [less than one per million] in association with the use of the AstraZeneca and Johnson and Johnson vaccines identified that have raised some public alarm regarding the Vaccine-Induced Immune Thrombotic Thrombocytopenia (VITT). Interestingly there are some pathological and clinical similarity between the well-established negatively charged Heparin-Induced Thrombocytopenia (HIT), that we are familiar with and VITT, that mostly occurs in some young predisposed female below the age of 30 but it is worthy to highlight that the potential for vaccine-inducing blood clot is comparatively at least 6-10 times lower than by the infection - induced thrombotic events, by the on-going coronavirus variants. Meanwhile as a cautionary measure VITT has been listed as a very rare side effect of the vaccine immunotherapy, much in line with the use of some antiviral and anti-inflammatory drugs and in fact the zero risks in any therapeutic intervention against $\mathrm{CoV}-2$ variants do not exist, but considerable variability observed in the host physiological response to vaccines and to $\mathrm{CoV}-2$ infection induced hypercoagulability. The development of a clot, at the early stages of the inflammatory thromboembolism can be easily contained but severe infection-induced organ injury with fatal outcome, without the use of vaccines as preventative or therapeutic intervention, are often beyond clinical repair. Neverthess, on the basis of the benefit versus risk analysis, the use of any approved vaccines, including AstraZeneca- types of vaccines, including Janssen, dictates without of any question that there is no need to overturning the unreturned stone. In fact, in this context there is a change of policy in the USA as after a week of fears and hesitation, they finally opted to pursue again the successful rollout of the Janssen vaccine, the first one dose vaccine design, and it is now back for use as a new armature to BEAT COVID and expectedly there is no changes in the UK rollout protocols are made due to fear of very rare potential side effects as almost 50 million doses of the types vaccines have been administered to the UK population without any major severe side effects. Clearly the use of more effective communication skills are essential to overcome high levels of vaccine hesitancy that still exist in some part of the world and some smart and intelligence led technologies and machine learning tools are essential to identify the best practice, despite 
the enormous progresses that we are witnessing have been made with success on passive immunotherapy to survive $\mathrm{CoV}-2$ variants and to save lives[1-8]. Currently attentions are focused on the development of targeted vaccines against variants and some booster bioproducts free from autoantibodies, activated complements and cytokines, as a safer and more effective coronavirus convalescent plasma-derived alternative therapies [9-15]. The journey in this direction is already begun but we need some urgent clinical trials to clearly establish their usefulness in the current health care system with more certainty, in particular in areas of poor economic infrastructure [16].

\section{References}

1. Seghatchian J (2020) An introductory commentary on the use of artificial intelligence, machine learning and TQM, as novel computational tools in big data patterns or procedural analysis, in transfusion medicine. Transfus Apher Sci 59: 102985. Link: https://pubmed.ncbi.nlm.nih.gov/33158743/

2. D'Alessandro A (2020) Benford's law and metabolomics: a tale of numbers and blood. Transfus Apher Sci 59: 103019. Link: https://bit.ly/34vCCC6

3. Seghatchian J (2021) New generation of vaccines and convalescent plasma therapy for the management of $\mathrm{CoV}-2$, in the global pandemic. Transfus Apher Sci 60: 103061. Link: https://bit.ly/3i2S8xd

4. Seghatchian J (2021) Editorial. Facts and challenges on global deployment of vaccines for the immunotherapy of the evolving SARS Cov-2 variants: What new year, with a fast spreading South African and the most fearful Brazilian variants, as the unwanted gifts, imposing enormous crises to surmount. Link: https://bit.ly/3uw6OHS

5. Seghatchian J, Acker JP, Putter JS (2020) Update on newer approaches to prevent or treat COVID-19 infection: what we all need the most right now. Transfus Apher Sci 59: 102933. Link: https://bit.ly/3yMI0Qs

6. Seghatchian J, Lanza F (2020) Convalescent plasma, an apheresis research project targeting and motivating the fully recovered COVID 19 patients: A rousing message of clinical benefit to both donors and recipients alike.
Transfus Apher Sci 59: 102794. Link: https://bit.ly/3vB9NQH

7. Lanza F, Agostini V, Monaco F, Passamonti F, Seghatchian J (2021) Therapeutic use of convalescent plasma in covid-19 infected patients with concomitant hematological disorders. Clinical Hematology International Link: https://bit.ly/3c400s0

8. Putter JS, Seghatchian J (2020) An update on COVID-19 infection contro measures, plasma-based therapeutics, corticosteroid pharmacotherapy and vaccine research. Transfus Apher Sci 59: 102934. Link: https://bit.ly/3vK823X

9. Amiral J, Vissac AM, Seghatchian J (2020) Covid-19, induced activation of hemostasis, and immune reactions: Can an auto-immune reaction contribute to the delayed severe complications observed in some patients? Transfus Apher Sci 59: 102804. Link: https://bit.ly/2RNrZbk

10. Alessandro D, Tiffany A, Dzieciatkowaska M, Hill RC, Richado F, et al. (2020) Serum proteomics in COVID-19 patients: altered coagulation and complement status as a function of IL-6 level. J Proteome Res 19: 4417-4427. Link: https://bit.ly/2Tvev4x

11. Mykhailova O, Seghatchain J, Acker J (2020) Assessment of extracellular vesicles using IFC for application in transfusion medicine. Transfus Apher Sci 59: 102942. Link: https://bit.ly/3c2aGKa

12. Picchianti Diamanti $A$, Rosado MM, Pioli C, Sesti G, Laganà $B$ (2020) Cytokine release syndrome in COVID-19 patients, a new scenario for an old concern The fragile balance between infections and autoimmunity. Int J Mol Sci 21: 3330. Link: https://bit.ly/3i8Ts1A

13. Varga Z, Flammer AJ, Steiger $P$, Haberecker $M$, Andermatt R, et al. (2020) Endothelial cell infection and endotheliitis in COVID-19. Lancet 395: 1417 1418. Link: https://bit.ly/3fykY7k

14. Connors JM, Levy JH (2020) Thromboinflammation and the hypercoagulability of COVID-19. J Thromb Haemost 18: 1559-1561. Link: https://bit.ly/3ieQau7

15. Chen G, Zhou Y, Ma J, Xia P, Qin Y, et al. (2020) Is there a role for blood purification therapies targeting cytokine storm syndrome in critically severe COVID-19 patients? Renal Failure 42: 483-488. Link: https://bit.ly/3yLUp5U

16. Smit Sibinga CT, Abdella YE, Seghatchian J (2020) Poor economics Transforming challenges in transfusion medicine and science into
Discover a bigger Impact and Visibility of your article publication with

\section{Peertechz Publications}

Copyright: @ 2021 Seghatchian J. This is an open-access article distributed under the terms of the Creative Commons Attribution License, which permits unrestricted use, distribution, and reproduction in any medium, provided the original author and source are credited. 